\title{
Integrating cereal genomics to support innovation in the Triticeae
}

\author{
C. Feuillet • N. Stein • L. Rossini • S. Praud • K. Mayer • \\ A. Schulman • K. Eversole • R. Appels
}

Received: 29 October 2012 / Accepted: 31 October 2012 /Published online: 17 November 2012

(C) The Author(s) 2012. This article is published with open access at Springerlink.com

\begin{abstract}
The genomic resources of small grain cereals that include some of the most important crop species such as wheat, barley, and rye are attaining a level of completion that now is contributing to new structural and functional studies as well as refining molecular marker development and mapping strategies for increasing the efficiency of breeding processes. The integration of new efforts to obtain reference sequences in bread wheat and barley, in particular, is accelerating the acquisition and interpretation of genome-level analyses in both of these major crops.
\end{abstract}

Keywords Genetics · Genomics · Map-based cloning ·

Molecular breeding · Comparative genomics .

Bioinformatics $\cdot$ Physical mapping $\cdot$ Wheat $\cdot$ Barley .

Triticeae

\section{Feuillet $(\square)$}

INRA-UBP UMR 1095 Genetics and Diversity of Cereals,

Clermont-Ferrand, France

e-mail: catherine.feuillet@clermont.inra.fr

\section{N. Stein}

Leibniz Institute of Plant Genetics and Crop Plant Research,

Gatersleben, Germany

L. Rossini

Dipartimento di Produzione Vegetale, Università degli Studi

di Milano,

Milan, Italy

S. Praud

Biogemma, Site de la Garenne,

90126, Chappes, France

\section{K. Mayer}

Munich Information Center for Protein Sequences/Institute for Bioinformatics and Systems Biology, Helmholtz Center Munich, Neuherberg, Germany

\section{Introduction}

For many years, the size and complexity of the Triticeae genomes, namely, wheat (17Gb, hexaploid), barley $(5 \mathrm{~Gb}$, diploid), and rye ( $8 \mathrm{~Gb}$, diploid), have hampered the development of genomics and its application to breed crops with improved composition and characteristics designed to satisfy the needs of consumers, processors, and producers. Despite the recognition that a reference genome sequence is key to accelerating crop improvement, the Triticeae are the last major crops for which a complete genome sequence is not available (Feuillet and Eversole 2007). Thus, the establishment of genome sequence enabled technology platforms for the Triticeae has lagged behind advances in other cereal crops such as corn and rice. In the past decade, however, extensive efforts to develop whole-genome and chromosome-specific bacterial artificial chromosome (BAC) libraries (Allouis et al. 2003; Safar et al. 2004), extensive EST collections (ITEC

A. Schulman

MTT/BI Institute of Biotechnology, University of Helsinki,

Helsinki, Finland

A. Schulman

Plant Genomics Laboratory, MTT Agrifood Research, Jokioinen, Finland

K. Eversole

Eversole Associates,

Wyoming Road,

5207, Bethesda, USA

R. Appels

Center for Comparative Genomics, Murdoch University, Perth, WA 6150, Australia 
http://avena.pw.usda.gov/genome/; Lazo et al. 2004; Zhang et al. 2004), transformation systems, wild germplasm and mutant collections, as well as DNA chips have permitted the establishment of large-scale genomics resources and research programs aimed at enabling high-quality sequencing of the Triticeae genomes. Given their complexity, in particular that of the hexaploid wheat genome, physical maps must be established as a scaffold for sequence assembly as it is simply not possible to achieve a reference genome sequence using whole genome shotgun approaches (Feuillet et al. 2011; Ariyadasa and Stein 2012). In the past 4 years, a number of initiatives such as the International Wheat Genome Sequencing Consortium (www.wheatgenome.org; Feuillet and Eversole 2007), the International Barley Sequencing Consortium (www.barleygenome.org), the UK wheat consortium (http://www.wheatbp.net/WheatBP/Documents/DOC Research.php), and the European TriticeaeGenome FP7 project (www.triticeaegenome.eu) have developed a suite of genomic resources and knowledge to provide the foundation for physical mapping and sequencing the wheat and barley genomes. Before the development of these resources, mapbased cloning was quite laborious and time-consuming, and consequently, only a few genes have been isolated in the Triticeae (Büschges et al. 1997; Brueggeman et al. 2002; 2008; Huang et al. 2003; Yan et al. 2003; Charles et al. 2009; Fu et al. 2009; Turner et al. 2005; Komatsuda et al. 2007; Taketa et al. 2008; Nair et al. 2010; Faris et al. 2010; Breen et al. 2010a; Bulgarelli et al. 2010; Yuo et al. 2012; for reviews see Stein and Graner 2004 and Krattinger et al. 2009). This was due in part to the challenge of walking efficiently along the chromosomes in repetitive sequence regions with the difficulty of identifying unique probes for screening BAC libraries. With more than $80 \%$ of the sequence identified as transposable elements, the issues are acute in the Triticeae genomes, although the deployment of markers that cross the often unique boundaries between repetitive elements has reduced the problem to some degree (Flavell et al. 1998; Paux et al. 2010). With physical maps in hand, chromosome walking is no longer necessary and, assuming the genetic resolution is high enough, physical maps enable direct landing at the target site thereby enabling more efficient gene cloning.

In the absence of complete genome sequences and given the relatively high gene order conservation (collinearity) observed in the grass genomes, genomics studies in the Triticeae have utilized comparative genomics approaches with other grass genomes. To date, five genomes relevant to the Triticeae have been sequenced, namely rice, Brachypodium, sorghum, maize, and foxtail millet (IRGSP 2005; IBI 2010; Paterson et al. 2009; Schnable et al. 2009; Bennetzen et al. 2012; Zhang et al. 2012). Comparisons between these different genomes enable the identification of conserved gene regions that can support molecular marker design and identify candidate genes for traits that are well conserved between species. Hence, the high-quality rice genome sequence (IRGSP 2005) combined with the sequences of a number of genomes from the other grasses (Brachypodium, sorghum, maize) was used to develop molecular markers such as the Conserved Orthologous Set (COS) molecular markers (Bertin et al. 2005; Quraishi et al. 2009) and to accelerate discovery of wheat and barley genes (Fu et al. 2009; Breen and Bellgard 2010; Rustenholz et al. 2010; Krattinger et al. 2011; Distelfeld et al. 2012). However, genes such as very recently duplicated genes and those involved in end use quality (for example bread, pasta), rapidly evolving genes such as disease resistance genes, as well as genes involved in large regulatory networks are more species-specific, and thus, it is crucial to have access to genomic resources and a reference sequence of the target genome.

\section{Establishment of genome resources for physical mapping in the Triticeae}

While for barley, whole genome BAC libraries have been produced (Schulte et al. 2011), the generation of BAC clones from flow-sorted chromosomes (Safar et al. 2004; Šafár et al. 2010) and chromosome arms (reviewed in Dolezel et al. 2012) has been key to reducing the complexity of the hexaploid wheat genome analyses. Typically, libraries of 30,000-90,000 BAC clones are generated from the flow sorting of approximately a million chromosomes (http:// olomouc.ueb.cas.cz/dna-libraries/cereals) to give a coverage of over $10 \times$ for the predicted chromosome size (Dolezel et al. 2007). The BAC libraries are then fingerprinted using SnapShot labelling and analysis (Luo et al. 2003), using five restriction endonucleases, and BAC contigs are assembled generally using the FingerPrinted Contig (FPC) software (Soderlund et al. 2000). Although efficient guidelines and methodologies were established (Appels et al. 2010) and good results were obtained in wheat, as exemplified by the construction of the first physical map of the $1 \mathrm{~Gb}$ wheat chromosome 3B (Paux et al. 2008), the length of the physical contigs was slightly lower than in small model genomes. Sequencing BAC contigs (Choulet et al. 2010) revealed a number of systematic errors in the FPC assemblies. In fact, due to the high level of repetitive DNA in the Triticeae genomes, very stringent criteria must be used to ensure a reliable assembly with the FPC software. This, in turn, often results in short contig lengths as well as an unreliable assembly in some difficult regions. To address these problems, Frenkel et al. (2010) developed a novel algorithm called Linear Topology Contig (LTC). The LTC algorithm reduces the rate of false connections and Q-clones by systematically exploring the topological contig structure and performing iterative clone clustering and ordering so that highly reliable and contigs longer than in FPC are 
recovered. The LTC detects "weak" connections in contigs obtained by FPC and through iterative steps undertakes their "repair."

A further improvement in the reliability of physical map construction can be obtained using the power of nextgeneration sequencing technologies. KeyGene (www. keygene.com) recently developed a new approach called Whole Genome Profiling (WGP, van Oeveren et al. 2011) that is based on the sequencing of the ends of restriction endonuclease fragments after digestion of BAC pools. The application of WGP to a subset of the wheat chromosome 3B physical map (Philippe et al. 2012) demonstrated that this is a viable approach for a complex genome such as wheat and that it reduces the amount of chimeric and misassembled clones compared to the SNAPshot method while providing sequence tag information that can be used to support pooling strategies for sequencing. Thus, robust methodologies and protocols are now in place for assembling reliable physical maps in the Triticeae genomes.

\section{Construction of anchored physical maps}

The full potential of physical maps in supporting map-based cloning and marker development for breeding can only be achieved when the BAC contigs are linked sufficiently to genetic and phenotypic maps. Thus, once physical maps have been assembled, it is essential that the BAC contigs are anchored at high density with molecular markers. This requires the development of thousands of markers followed by their assignation to the genetic and physical maps. In the Triticeae, large collaborative efforts have been deployed in the past 15 years to develop EST and SSR markers for genetic mapping enabling the construction of genetic maps that carry several hundreds of markers (wheat.pw.usda.gov/ GG2/index.shtml). However, it is only with the advent of NGS technologies that high throughput development and genotyping of SNP markers progressed to a significant degree in wheat and barley. This has opened up new perspectives in anchoring strategies (Sorrells et al. 2011; Paux et al. 2012; Allen et al. 2011; Poland et al. 2012). The deployment of KASpar-based assays for SNPs in wheat provided the basis for a map of Avalon $\times$ Cadenza with 2,923 SNPs (Allen et al. 2011) and Savannah $\times$ Rialto with 1,412 SNPs (http//www.wheatisp.org). Recently, large transcriptome sequencing and resequencing efforts in Australia and the USA enabled the development of a 9K Infinium wheat SNP-chip (Akunov, personal communication). In barley, comprehensive sets of several thousands of SNP markers have been successfully developed and mapped in numerous populations (Close et al. 2009; Muñoz-Amatriaín et al. 2011; Comadran et al. 2012). With additional genebased SNP datasets originating from programs in the UK (http://www.wheatisp.org; Allen et al. 2011) and from 5,000 COS-SNPs designed in the TriticeaeGenome project, a $90 \mathrm{~K}$ SNP-chip is currently under design and should be available in the near future (Akhunov, personal communication). Focusing on the transcriptome enables a reduction in complexity that also can be achieved by the digestion of genomic DNA with restriction enzymes and sequencing of selected fragments. Genotyping by sequencing (GBS) technologies, developed originally in maize, have been applied to wheat and barley (Elshire et al. 2011; Poland et al. 2012) thereby providing another platform for DNA sequence-based ordering of reference points along the Triticeae genomes. With this approach, 34,396 SNPs were mapped by GBS in the Oregon Wolfe barley reference population, while 19,720 SNPs were mapped in the synthetic W97846 $\times$ Opata 85 reference wheat population. Because they rely on sequence information, the SNP- and GBS-based approaches provide thousands of sequence tags that can be integrated into physical maps in silico thereby increasing the efficiency of anchoring strategies. This more direct integration of BAC sequencing and anchoring to genetic maps was carried out successfully in the rice genome sequencing program using BAC-end sequences (reviewed in Ariyadasa and Stein 2012), and it is currently being applied in wheat and barley (IBSC 2012). The in silico, sequence-based anchoring complements the well-established process of identifying known molecular markers in BAC pools using PCR (Paux et al. 2008) as well as the broad range of hybridization array technologies that are available (reviewed in Ariyadasa and Stein 2012).

Genetic mapping in the Triticeae genomes is difficult partly as a result of the very low rate of recombination observed in the centromeric and pericentromeric regions that can represent up to one half of an entire chromosome (Birchler et al. 2009; Kanisay and Dawe 2009). On wheat chromosome 3B, it was estimated that $90 \%$ of crossing over occur in only $40 \%$ of the chromosome, mostly in the telomeric regions, whereas $27 \%$ of the chromosome did not show any crossing over (Saintenac et al. 2009). In the recombinogenic regions, sufficient resolution in ordering physical contigs to genetic maps using molecular markers can be obtained when utilizing mapping populations with high recombination frequencies. This can be achieved using recombinant inbred line (RIL) populations of several thousand individuals. Two populations of 2,600 and 4,000 RILs have been produced for this purpose in wheat (Renan $\times$ Chinese Spring) and barley (Barke $\times$ Morex), respectively, in the TriticeaeGenome project with the rationale of using parents that are the references for genome sequencing and physical mapping, i.e., Chinese Spring in wheat and Morex in barley. This complements the continued efforts of the International Triticeae Mapping Initiative to develop a reference population for genetic mapping in wheat using a 
cross between the synthetic wheat W7984 $\times$ Opata M85 population. A new population of 2,039 RILs has been established recently with a core set of 42 SSR markers used to genotype the lines and facilitate a community-base effort to build a detailed map (Sorrells et al. 2011). In addition, Sorrells et al. (2011) reported 215 doubled haploid lines that were genotyped with 1,446 molecular markers. Furthermore, multi-parent advanced generation intercross populations originating from multiple founder lines (typically 8 to 16) and therefore relying on a larger diversity and amount of recombination events than bi-parental populations have been established in wheat (Mackay and Powell 2007; Huang et al. 2012). These are currently being tested for anchoring physical maps in different projects.

In the regions near the centromeres or within large blocks of heterochromatin where little if any recombination occurs, it is not possible to reliably anchor and order a physical map. Targeting these regions is important, however, as it is now clear that genes are present all along the physical maps (Choulet et al. 2010; Rustenholz et al. 2011), including in $\mathrm{BAC}$ clones assigned to the centromeres and to retrotransposable element-rich regions of chromosomes. Genes, including the important vernalisation gene $\mathrm{Vrn}$ - $\mathrm{D}$ 4, have been mapped to the centromere region (Yoshida et al. 2010). In another study, the characterization of a $0.8-\mathrm{Mb}$ DNA segment from chromosome 3B that was composed almost entirely of transposable elements except for a small gene island of three conserved genes (Breen et al. 2010b). Thus, an alternative strategy for targeting centromeres and other repetitive sequence-rich regions of the chromosomes where recombination is low has been established following radiation hybrid mapping approaches that are widely used in animal genetics. Radiation hybrid mapping relies on assaying radiation-induced chromosomal fragments with molecular markers defined by the physical map under study (Riera-Lizarazu et al. 2010). The frequency of markers remaining together on the same chromosome fragment defines a measure of how physically close the markers are to each other. RH mapping was evaluated during the construction of the 3B physical map using a panel of $184 \mathrm{RH}$ lines tested with 65 ISBP markers. A resolution of approximately $263 \mathrm{~kb}$ per break was observed (Paux et al. 2008). In particular, for the terminal bin of chromosome 3BL (3BL70.63-1.00), 35 loci corresponding to 32 loci were ordered and confirmed the physical map established using markers ordered by standard recombination-based mapping (Paux et al. 2008). More recently, the same panel was used to establish a high density RH map with 541 marker loci anchored to chromosome 3B spanning a total distance of $1871.9 \mathrm{cR}$ (Kumar et al. 2012).

The observations on the existence of a core set of coding genes that is conserved among the grass genomes (Salse et al. 2009) have also provided a basis for anchoring chromosome (arm) specific DNA sequences to genetic and physical maps (Mayer et al. 2009; Berkman et al. 2011; Berkman et al. 2012). The so-called chromosome zipper approach was developed originally in barley to determine a virtual order of genes using inference of synteny information along the grass genomes (Mayer et al. 2009, 2011). Incorporation of chromosome arm-specific microarray hybridization information is providing an important crossreference for the positioning of genes in this framework. In addition, cross-referencing to BAC clones that contain particular genes identified by DNA hybridisation helps in ordering BAC and FPC contigs. Typically 4,000-9,000 genic sequences per chromosome are found for wheat chromosomes, with some likely to represent gene fragments and pseudogenes (Choulet et al. 2010; Wicker et al. 2011). Following their identification, genes conserved between wheat, Brachypodium, rice, sorghum, and barley (Hernandez et al. 2012) can then be clustered into syntenic groups and, along with dense genetic marker information, used to define an estimated gene order in wheat and barley. The analysis also identifies predicted genes that may be unique to wheat and barley and thus might be significant in accounting for the specific agronomic attributes of these crops.

High throughput hybridization platforms can be used for anchoring physical maps if arrays of mapped markers are hybridized to labelled pools of BACs (Rustenholz et al. 2010; Hui et al. 2011; Ariyadasa and Stein 2012). The hybridization of DNA from complex genomes to microarrays with long oligonucleotides that assay different clusters of multiple SNPs, small deletion/insertion differences, copy number variants, and presence/absence variation in genomic DNA rather than single SNPs have also been used to assay polymorphisms for genotyping (Fu et al. 2010). In the case of chromosome 3B, pools of BACs were hybridised to a barley Agilent $15 \mathrm{~K}$ expression microarray and allowed 738 barley orthologous genes to be located to their respective BAC clones (Rustenholz et al. 2010). The study showed that $68 \%$ of the genes identified in the study were syntenic between wheat chromosome $3 \mathrm{~B}$ and barley $3 \mathrm{H}$.

\section{Comparative genomics reveals unique features of the Triticeae genomes}

Analyses of the grass genomes have pioneered the field of comparative genomics in plants. Early analyses of ribosomal DNA loci in the Triticeae (Dubcovsky and Dvorak 1995) indicated that despite a good conservation between the genomes, specific rearrangements occurred. Indications for this conclusion were already evident in BAC sequencing and comparison during map-based cloning projects. More recently, the construction of physical maps and whole chromosome analyses demonstrated that $30-40 \%$ of the gene 
complements in wheat and barley do not reside in the conserved syntenic gene order space (Choulet et al. 2010; Mayer et al. 2011; Wicker et al. 2011; Berkman et al. 2012).

Rearrangements including deletions and expansions in the genomes of wheat have been frequent (Dubcovsky and Dvorak 2007; Wicker et al. 2011) and are considered to be the result of waves of retrotransposable elements' movements assumed to have occurred in the recent evolutionary history of wheat (Charles et al. 2008; Choulet et al. 2010). In the case of the rDNA loci in the Triticeae, a further variable includes amplification events that increase the number of tandem copies of the genes at a given locus (Dubcovsky and Dvorak 1995). Additional mechanisms for rearrangements suggested by Wicker et al. (2011) include the repair of double-strand breaks in DNA which can include a DNA segment (plus or minus a gene sequence) from elsewhere in the genome. Although Wicker et al. (2011) argued that pseudogenes mostly arise from genome rearrangements, unique gene-domain fusions have been reported to be important in generating a gene that confers temperaturedependent resistance to wheat stripe rust wheat $(\mathrm{Fu}$ et al. 2009) and sensitivity to the tan spot pathogen (Faris et al. 2010). In both of these examples, protein kinase domains were fused with domains that could be recognized as being important in disease resistance gene networks.

The instability of the wheat genome was dramatically illustrated by Wicker et al. (2011) in an analysis of the short arm of chromosome 1D (1DS) which exists as a ditelosomic chromosome in a standard genetic stock of wheat used for chromosome sorting. Gene sequences for 1DS were assigned to two regions of Brachypodium chromosome 2, syntenic regions $1 \mathrm{~S}$ and $1 \mathrm{~L}$, even though these Brachypodium regions are clearly differentiated when alignments with gene sequences from the ditelosomics 1AS, 1BS and $1 \mathrm{AL}, 1 \mathrm{BL}$ are carried out. In addition, the wheat ESTs mapping to the proximal region of 1DS in independent studies were also missing from the ditelo 1DS sequence dataset (Wicker et al. 2011).

In addition to providing the basis for analyzing conserved gene orders on a large scale (as described earlier), comparative genomics has been important in wheat and barley to define conserved features of genes, and several examples are now available for the identification of candidate genes for the phenotypes being studied. The characterization of the Vrn genes in wheat and barley (Yan et al. 2003, 2004, 2006; Yoshida et al. 2010) was facilitated by comparative analyses across wheat, barley, and rice. The importance of modifications in intron 1 for variation in expression of the $\mathrm{Vrn}$ genes was established through the analysis of allelic variants. A comparison to variants in Lolium perenne (Asp et al. 2011) showed that INDELS in several different locations within intron 1 could modify $\mathrm{Vrn} 1$ expression. Additional examples include the identification of the bract suppression gene
$\operatorname{Trd1}$, a GATA transcription factor, on barley $1 \mathrm{H}$ through fine mapping and anchoring of the phenotype to a syntenic region in rice (Houston et al. 2012), the boron toxicity tolerance gene on barley $4 \mathrm{H}$ (Sutton et al. 2007), the RhtD1 gene region on 4D (Duan et al. 2012), and the NAC transcription factor on wheat 6B (Distelfeld et al. 2004, 2012). In the case of the NAC transcription factor, the functional attributes appeared to be quite different in rice and wheat (Distelfeld et al. 2012) and indicated extrapolating function based on shared DNA sequence structure may not always be possible.

\section{Gene isolation and new allele discovery}

The unique features of the Triticeae genomes emphasize the importance of high-resolution mapping populations and physical maps developed in the target species to enable the de novo identification of genes that are unique to wheat and barley biology, as well as genes underlying QTLs. As genes and gene regions of interest are identified, targeted resequencing (Saintenac et al. 2011; Winfield et al. 2012) provides a valuable methodology for identifying new alleles in related varieties or wild relatives. The recent progress in high throughput marker development combined with new association genetics panels, physical maps, and survey sequences represent a breakthrough in map-based cloning in the Triticeae. In wheat, physical maps of chromosome 1A, 1B, 3A, 3B, and 3D (http://urgi.versailles.inra.fr/gb2/ gbrowse/wheat_phys_pub/) as well as survey sequences of all 21 individual bread wheat chromosomes are already available on line (http://urgi.versailles.inra.fr/Species/ Wheat/Sequence-Repository). In barley, a physical map, survey sequences of sorted chromosomes, several thousand of shotgun sequenced BAC clones and whole genome shotgun sequence assemblies were integrated to a physical/genetic genome scaffold providing an excellent template for accelerated map-based cloning and comparative genomebased candidate gene identification (IBSC 2012) (http://mips. helmholtz-muenchen.de/plant/triticeae/barleyDisclaimer.jsp; $\mathrm{http}: / /$ webblast.ipk-gatersleben.de/barley). As an example, in the Triticeae more than 15 gene and QTL projects are benefiting already from access to these resources (Table 1) and, since the reference sequence of chromosome 3B is underway, 343 scaffolds accounting for $29 \mathrm{Mb}$ targeting 74 BAC-contigs sequences have already been provided to laboratories worldwide. Once candidate genes are identified, functional validation is needed to ascertain the function of the candidate. Both reverse and forward genetics approaches are now well established for wheat and barley. Stable (Agrobacterium, biolistic) and transient (VIGS) transformation systems are performed routinely in many laboratories worldwide, and mutagenized collections have been produced in both wheat and barley. In 
Table 1 Examples of gene and QTL projects benefiting from the access to wheat and barley physical maps and sequences

\begin{tabular}{|c|c|c|c|c|c|c|}
\hline Locus & Trait & Chromosome & Species & Organization & PI & $\begin{array}{l}\text { Use of physical map/sequence } \\
\text { information }\end{array}$ \\
\hline YrH52 & Stripe rust resistance & $1 B S$ & Emmer wheat & $\begin{array}{l}\text { University of } \\
\text { Haifa- Israel }\end{array}$ & T. Fahima & $\begin{array}{l}2 \text { physical non-overlapping contigs } \\
\text { identified (total of } 3.7 \mathrm{Mb} \text { with } \\
\text { estimated gap of } 0.4 \mathrm{Mb} \text { ) }\end{array}$ \\
\hline$P V-Q T L$ & Fiber content (QTL) & $1 B L$ & Bread wheat & INRA - France & J. Salse & $\begin{array}{l}1 \text { physical map contig }(645 \mathrm{~kb}) \\
\text { anchored to co-segregating COS } \\
\text { CG marker }\end{array}$ \\
\hline QSng.sfr & $\begin{array}{l}\text { Glume blotch } \\
\text { resistance (QTL) }\end{array}$ & $3 B S$ & Bread wheat & $\begin{array}{l}\text { University of } \\
\text { Zurich- } \\
\text { Switzerland }\end{array}$ & B. Keller & 3 sequenced contigs identfied $(1.58 \mathrm{Mb})$ \\
\hline QYld.idw & Yield (QTL) & $3 B S$ & Durum wheat & $\begin{array}{l}\text { University of } \\
\text { Bologna-Italy }\end{array}$ & R. Tuberosa & $\begin{array}{l}\text { Region }<200 \mathrm{~kb} \text { in the physical map } \\
\text { containing } 4 \text { candidate genes }\end{array}$ \\
\hline$S r 2$ & Stem rust resistance & $3 B S$ & Bread wheat & $\begin{array}{l}\text { CSIRO and Murdoch } \\
\text { University }\end{array}$ & W. Spielmeyer & $\begin{array}{l}1 \text { sequenced contig }(1.26 \mathrm{Mb}) \text { spanning } \\
\text { the } \mathrm{Sr} 2 \text { genetic interval }\end{array}$ \\
\hline$S V 2$ & Leaf rust resistance & $3 B S$ & Bread wheat & INTA-Argentina & MJ. Dieguez & $\begin{array}{l}2 \text { sequenced contigs }(1,2 \text {, and } 3 \mathrm{Mb}) \\
\text { identified with flanking markers used } \\
\text { for marker development, screening of } \\
\text { BAC library from resistant cultivar } \\
\text { and candidate gene identification }\end{array}$ \\
\hline SSt 1 & $\begin{array}{r}\text { Solid stem (saw } \\
\text { fly resistance) }\end{array}$ & $3 B$ & Durum wheat & $\begin{array}{l}\text { University of } \\
\text { Saskatchewan- } \\
\text { Canada }\end{array}$ & C. Pozniak & $\begin{array}{l}17 \text { sequenced contigs identified for } \\
\text { marker development, } 8 \text { new } \\
\text { cosegrating markers developed }\end{array}$ \\
\hline$Q F t-3 B$ & Flowering time (QTL) & $3 B S$ & Bread wheat & IEB-Czech republic & J. Safar & $\begin{array}{l}38 \text { sequenced contigs identified for } \\
\text { marker development }\end{array}$ \\
\hline Qcrs.cpi-3B & Crown rot (QTL) & $3 B S$ & Bread wheat & CSIRO_-Australia & C. Liu & $\begin{array}{l}53 \text { sequence contigs identified for } \\
\text { marker development }\end{array}$ \\
\hline$P m 41$ & Powdery mildew & $3 B L$ & Bread wheat & $\begin{array}{l}\text { China Agricultural } \\
\text { University_China }\end{array}$ & Z. Liu/Z. Wang & $\begin{array}{l}9 \text { sequence contigs identified for marker } \\
\text { development }\end{array}$ \\
\hline$q D H Y .3 B L$ & $\begin{array}{l}\text { Drought tolerance } \\
\text { (QTL) }\end{array}$ & $3 B L$ & Bread wheat & ACPFG-INRA & $\begin{array}{l}\text { P. Langridge- } \\
\text { C. Feuillet }\end{array}$ & $\begin{array}{l}9 \text { sequence contigs identified for marker } \\
\text { development and candidate gene } \\
\text { identification }\end{array}$ \\
\hline $\operatorname{Yr} 49$ & Yellow rust resistance & $3 D S$ & Bread wheat & CSIRO_Australia & W. Spielmeyer & $\begin{array}{l}\text { Contig at the proximal side identified, } \\
\text { contig at distal side not identified yet, } \\
\text { and cosegregating contig identified }\end{array}$ \\
\hline cul4 & Tillering & $3 H$ & Barley & $\begin{array}{l}\text { University of Milan } \\
\text { - Italy }\end{array}$ & L. Rossini & $\begin{array}{l}\text { One BAC spanning the cul4 genetic } \\
\text { interval and candidate gene } \\
\text { identified and sequenced }\end{array}$ \\
\hline
\end{tabular}

wheat, several mutant populations have been produced in diploid, tetraploid, and hexaploid genetics backgrounds, and projects are underway to establish TILLING by sequencing (Tsai et al. 2011). In barley, TILLING resources have been established (Caldwell et al. 2004; Talamè et al. 2008; Gottwald et al. 2009) that show a wide range in phenotype diversity for the discovery of genes contributing to the complex networks that underpin plant phenotypes. In parallel, natural allelic variation can also be explored by EcoTILLING approaches and associated to phenotypic variation (Xia et al. 2012).

In Table 1, a summary is provided for traits and their respective genes that have been defined in wheat and barley. The table focuses on a list of genes on the group 1 and 3 chromosomes in wheat and barley. At a broader level, in addition to identifying the genes for disease resistance, grain quality traits have also been well defined at the DNA level. Examples include the low and high molecular weight glutenin subunit loci on the group 1 chromosomes important for flour processing quality, and the $\mathrm{Ha}$ locus on 5D defining the soft/hard attributes of the grain (Chantret et al. 2005; Charles et al. 2009).

\section{Application in molecular breeding}

Increased density of markers along genetic and physical maps using array-based techniques for genes and insertion sequence-based polymorphism markers as well as GBS in wheat and barley enable breeders to perform accurate association mapping studies (Heffner et al. 2010; Liu et al. 2012). Association genetics has only been recently applied to crop plants, (Mackay and Powell 2007) yet it is an exciting alternative to conventional QTL mapping in biparental crosses. It draws on the principle that linkage disequilibrium (LD) tends to be maintained over many generations 
between loci which are physically linked to one another. Panels of non-related lines represent many cycles of historical recombinations compared to typical QTL mapping populations. LD will likely decay very rapidly with genetic distance if the panel used consists of very diverse lines; thus, correlations between marker and QTL will be identified only if the marker is tightly linked to the QTL (Paux et al. 2012; Miedaner and Korzun 2012). The number of markers needed to accomplish such studies therefore increases with the diversity of the panel, and a balance must be found between the resolution of the panel and the power to detect associations. Barley and wheat can now rely on the genomics tools described above to develop large quantities of molecular markers.

However, to take the full advantage of these resources, it is essential that adapted association panels are developed. In the past years, several elite panels have been developed for wheat and barley, notably for European germplasm. Le Couviour et al. (2011) described a panel of 195 Frenchgrown elite winter wheat varieties. Reif et al. (2011) used a 455 central European winter wheat varieties panel for association mapping of QTL for grain yield, heading date and Fusarium Head Blight resistance, while Cockram et al. (2010) studied a 500 barley cultivar panel for 15 morphological traits. In the TriticeaeGenome project, breeders from France, the UK, and Germany established a panel of 376 varieties based on (1) general phenotypic levels of adaptation to field conditions, (2) phenotypic homogeneity, and (3) genotypic diversity. This panel has been used for genotyping and phenotyping adaptive traits such as yield, heading date, and plant height. It has been distributed to colleagues in India and Argentina who are interested in identifying new alleles in European winter wheat and is accessible for further collaboration. Thus, most of the material currently grown in Europe for wheat and barley is represented in one panel or another. The TriticeaeGenome panel and the one developed by Reif et al. (2011) are complementary resources to investigate traits in western and central European wheat germplasm that could be used to cross-validate QTL regions. Reif et al. (2011) identified QTL underlying grain yield on chromosomes $1 \mathrm{~B}, 1 \mathrm{D}, 2 \mathrm{~A}, 4 \mathrm{~A}, 4 \mathrm{D}, 5 \mathrm{~A}, 5 \mathrm{~B}$, and $7 \mathrm{~A}$ and heading date on chromosomes $1 \mathrm{~B}, 2 \mathrm{~B}, 4 \mathrm{~B}, 4 \mathrm{D}$, 5A, 5D, and 7D. Moreover, the potential favorable alleles identified in these panels are more likely to be taken up by breeders as they will be already available in elite germplasm and more amenable for introduction into marker-assisted recurrent selection. Finally, genomic selection (GS) has been proposed as an alternative to use marker data in breeding that could correct some of the deficiencies in classical marker-assisted selection (Meuwissen 2009) and is the subject of further development in crop plants (Heffner et al. 2010). The TriticeaeGenome panel (376 individuals) represents a good example of the diversity in west European wheat, and it could be used to study GS in wheat. Indeed, the size of the TriticeaeGenome panel is sufficient to be divided into a training set and a validation set, and phenotypic data have already been gathered over 2 years in a total of seven locations. The panel itself is not linked to any commercial breeding programme, so it can be envisaged that both researchers and breeders use the resource.

\section{Bioinformatic tools and databases}

The Triticeae community established a unique database, GrainGenes (http://wheat.pw.usda.gov/), to provide a suite of services for the Triticeae and oat communities, including databases, documents, tools, data files, announcements, curation, and community assistance. To date, GrainGenes stores 76 wheat genetic maps, more than 100,000 genetic markers, and approximately 271,000 wheat ESTs. These sequences can be searched through a BLAST server or by using queries to get additional information on genetic mapping data. GrainGenes also hosts the Triticeae Repeat databank that comprises 1,717 sequences of wheat transposable elements. Another database, HarvEST (http://harvest. ucr.edu/) that is highly frequented by users of the Triticeae community provides access to curated EST assemblies of wheat and barley as well as meta data linking to marker resources and orthologs of related grasses (Close et al. 2008). With the developments in physical mapping and sequencing activities, new databases have emerged to integrate outputs from studies on wheat and barley. For example, the INRA URGI Wheat database (http://urgi. versailles.inra.fr/Species/Wheat) provides access to the physical maps of The TriticeaeGenome chromosome 1BL, $1 \mathrm{AS}, 3 \mathrm{~B}$, and $3 \mathrm{D}$ as well as to the $3 \mathrm{~A}$ physical map which is hosted at the WGGRC. Physical maps of cv. Chinese Spring chromosomes that are constructed under the framework of the IWGSC are being integrated regularly into the database (http://www.wheatgenome.org/Projects/IWGSC-BreadWheat-Projects/Physical-mapping/). A GBrowse displays the physical maps in relation with other datasets (e.g., genetic markers, reference sequences, QTLs, and SNPs). To date, the database stores 26 wheat genetic maps, 19,029 markers, 324 QTLs, 10,819 SNPs, and 544,529 ESTs. In addition, URGI hosts the IWGSC sequence repository that provides access to the survey sequence assemblies of the 21 chromosomes of Chinese Spring (http://urgi.versailles. inra.fr/Species/Wheat/Sequence-Repository). The URGI database is mirrored at the MIPS which host equivalent datasets for the barley genome (http://mips.helmholtzmuenchen.de/plant/barley/index.jsp).

In support of the international efforts to obtain reference sequences from rice (riceGAAS; http://ricegaas.dna.affrc. go.jp/) and the Triticeae, a versatile, easy-to-use online automated tool for annotation, a semi-automated annotation 
pipeline called TriAnnot has been developed (Leroy et al. 2012). Its modular architecture allows for the annotation and masking of transposable elements, the structural and functional annotation of protein-coding genes with an evidence-based quality indexing, and the identification of conserved noncoding sequences and molecular markers. To date, the TriAnnot pipeline is parallelized on a $712 \mathrm{CPU}$ computing cluster that can run a 1-Gb sequence annotation in less than $26 \mathrm{~h}$. When evaluated on rice and wheat data sets, TriAnnot systematically showed a higher level of reliability than other annotation pipelines that are not improved for wheat. As it is easily adaptable to the annotation of other plant genomes, TriAnnot should become a useful resource for the annotation of large and complex genomes in the future.

The rapid advances in wheat and barley provide the basis for the next steps in the efficient exploitation of the newly available resources for research and breeding. The international consortia discussed in this review have been successful in establishing an interface of cooperation to facilitate the exchange of genome sequence data and to increase the impact of advances on growers and breeding programs. Emerging technological advances in physical and genetic mapping, marker development and association genetics, bioinformatics and map-based cloning provide a foundation for step changes in germplasm development that would otherwise take a much longer period of time.

Open Access This article is distributed under the terms of the Creative Commons Attribution License which permits any use, distribution, and reproduction in any medium, provided the original author(s) and the source are credited.

\section{References}

Allen AM, Barker GLA, Berry ST, Coghill JA, Gwilliam R, Kirby S, Robinson P, Brenchley RC, D'Amore R, McKenzie N, Waite D, Hall A, Bevan M, Neil Hall N, Edwards KJ (2011) Transcriptspecific, single-nucleotide polymorphism discovery and linkage analysis in hexaploid bread wheat (Triticum aestivum L.). Plant Biotechnol J 2011:1-14

Allouis S, Moore G, Bellec A, Sharp R, Faivre Rampant P, Mortimer K, Pateyron S, Foote TN, Griffiths S, Caboche M, Chalhoub B (2003) Construction and characterisation of a hexaploid wheat (Triticum aestivum L.) BAC library from the reference germplasm 'Chinese Spring'. Cereal Res Comm 31:331-338

Appels R, Akhunov E, Alaux M, Caccamo M, Cattonaro F, Dolezel J, Edwards D, Luo MC, Matthews D, Guilhot N, Paul E, Wicker T, Eversole K and Feuillet C (2010) IWGSC: physical mapping standard protocols workshop report. In: W.G.R.C. Kansas State University (ed.) Plant and animal genome meeting vol. 56. San Diego, CA, USA, pp. 5-9

Ariyadasa R, Stein N (2012) Advances in BAC-based physical mapping and map integration strategies in plants. J Biomed Biotechnol 2012:184854

Asp T, Byrne S, Gundlach H, Bruggmann R, Mayer KFX, Andersen JR, Mingliang Xu M, Morten G, Lenk I, Lubberstedt T (2011) Comparative sequence analysis of VRN1 alleles of Lolium perenne with the co-linear regions in barley, wheat, and rice. Mol Genet Genom 286:433-447

Bennetzen JL, Schmutz J, Wang H, Percifield R, Hawkins J, Pontaroli AC, Estep M, Feng L, Vaughn JN, Grimwood J, Jenkins J, Barry K, Lindquist E, Hellsten U, Deshpande S, Wang X, Wu X, Mitros T, Triplett J, Yang X, Ye C-Y, Mauro-Herrera M, Wang L, Li P, Sharma M, Sharma R, Ronald PC, Panaud O, Kellogg EA, Brutnell TP, Doust AN, Tuskan GA, Rokhsar D, Devos KM (2012) Reference genome sequence of the model plant Setaria. Nat Biotech 30:555-561

Berkman PJ, Skarshewski A, Lorenc MT, Lai K, Duran C, Ling EY, Stiller J, Smits L, Imelfort M, Manoli S, McKenzie M, Kubaláková M, Šimková H, Batley J, Fleury D, Doležel J, Edwards D (2011) Sequencing and assembly of low copy and genic regions of isolated Triticum aestivum chromosome arm 7DS. Plant Biotechnol J 9:768-775

Berkman PJ, Skarshewski A, Manoli S, Lorenc MT, Stiller J, Smits L, Lai K, Campbell E, Kubaláková M, Simková H, Batley J, Doležel J, Hernandez P, Edwards D (2012) Sequencing wheat chromosome arm 7BS delimits the 7BS/4AL translocation and reveals homoeologous gene conservation. Theor Appl Genet 124:423-432

Bertin I, Zhu JH, Gale MD (2005) SSCP-SNP in pearl millet-a new marker system for comparative genetics. Theor Appl Genet 110:1467-1472

Birchler JA, Gao Z, Han F (2009) A tale of two centromeres - diversity of structure but conservation of function in plants and animals. Funct Integr Genom 9:7-13

Breen J, Bellgard M (2010) Germin-like proteins (GLPs) in cereal genomes: gene clustering and dynamic roles in plant defence. Funct Integr Genom 10:463-476

Breen J, Li D, Dunn DS, Békés F, Kong X, Zhang J, Jia J, Wicker T, Mago R, Ma W, Bellgard M, Appels R (2010a) Wheat beta-expansin (EXPB11) genes: identification of the expressed gene on chromosome 3BS carrying a pollen allergen domain. BMC Plant Biol 10:99

Breen J, Wicker T, Kong X, Zhang J, Ma W, Paux E, Feuillet C, Appels $\mathrm{R}$, Bellgard M (2010b) A highly conserved gene island of three genes on chromosome $3 \mathrm{~B}$ of hexaploid wheat: diverse gene function and genomic structure maintained in a tightly linked block. BMC Plant Biol 10:98

Brueggeman R, Rostoks N, Kudrna D, Kilian A, Han F, Chen J, Druka A, Steffenson B, Kleinhofs A (2002) The barley stem rustresistance gene Rpg1 is a novel disease-resistance gene with homology to receptor kinases. Proc Natl Acad Sci U S A 99 (14):9328-9333

Brueggeman R, Druka A, Nirmala J, Cavileer T, Drader T, Rostoks N, Mirlohi A, Bennypaul H, Gill U, Kudrna D, Whitelaw C, Kilian A, Han F, Sun Y, Gill K, Steffenson B, Kleinhofs A (2008) The stem rust resistance gene Rpg5 encodes a protein with nucleotidebinding-site, leucine-rich, and protein kinase domains. Proc Natl Acad Sci U S A 105(39):14970-14975

Bulgarelli D, Biselli C, Collins NC, Consonni G, Stanca AM, SchulzeLefert P, Valè G (2010) The CC-NB-LRR-type Rdg2a resistance gene confers immunity to the seed-borne barley leaf stripe pathogen in the absence of hypersensitive cell death. PLoS One 5(9): pii: e12599

Büschges R, Hollricher K, Panstruga R, Simons G, Wolter M, Frijters A, van Daelen R, van der Lee T, Diergaarde P, Groenendijk J, Töpsch S, Vos P, Salamini F, Schulze-Lefert P (1997) The barley Mlo gene: a novel control element of plant pathogen resistance. Cell 88(5):695-705

Caldwell KS, Dvorak J, Lagudah ES, Akhunov E, Luo M-C, Wolters P, Powell W (2004) Sequence Polymorphism in Polyploid Wheat and Their D-Genome Diploid Ancestor. Genetics 167:941-947

Chantret N, Salse J, Sabot F, Rahman S, Bellec A, Laubin B, Dubois I, Dossat C, Sourdille P, Joudrier P, Gautier MF, Cattolico L, Beckert M, Aubourg S, Weissenbach J, Caboche M, Bernard M, Leroy P, Chalhoub B (2005) Molecular basis of evolutionary events that 
shaped the hardness locus in diploid and polyploid wheat species (Triticum and Aegilops). Plant Cell 17:1033-1045

Charles M, Belcram H, Just J, Huneau C, Viollet A, Couloux A, Segurens B, Carter M, Huteau V, Coriton O, Appels R, Samain S, Chalhoub B (2008) Dynamics and differential proliferation of transposable elements during the evolution of the $\mathrm{B}$ and $\mathrm{A}$ genomes of wheat. Genetics 180:1071-1086

Charles M, Tang H, Belcram H, Paterson A, Gornicki P, Chalhoub BP (2009) Sixty million years in evolution of soft grain trait in grasses: emergence of the softness locus in the common ancestor of Pooideae and Ehrhartoideae, after their divergence from Panicoideae. Mol Biol Evol 26:1651-1661

Choulet F, Wicker T, Rustenholz C, Paux E, Salse J, Leroy P, Schlub S, Le Paslier MC, Magdelenat G, Gonthier C, Couloux A, Budak H, Breen J, Pumphrey M, Liu S, Kong X, Jia J, Gut M, Brunel D, Anderson JA, Gill BS, Appels R, Keller B, Feuillet C (2010) Megabase level sequencing reveals contrasted organization and evolution patterns of the wheat gene and transposable element spaces. Plant Cell 22:1686-1701

Close TJ, Wanamaker S, Roose ML, Lyon M (2008) HarvEST. In: Edwards D (ed) Plant bioinformatics. Humana Press, pp 161-177

Close TJ, Bhat PR, Lonardi S, Wu Y, Rostoks N, Ramsay L, Druka A, Stein N, Svensson JT, Wanamaker S, Bozdag S, Roose ML, Moscou MJ, Chao S, Varshney RK, Szücs P, Sato K, Hayes PM, Matthews DE, Kleinhofs A, Muehlbauer GJ, DeYoung J, Marshall DF, Madishetty K, Fenton RD, Condamine P, Graner A, Waugh R (2009) Development and implementation of highthroughput SNP genotyping in barley. BMC Genom 10:582

Cockram J, White J, Zuluaga DL, Smith D, Comadran J, Macaulay M, Luo Z, Kearsey MJ, Werner P, Harrap D, Tapsell C, Liu H, Hedley PE, Stein N, Schulte D, Steuernagel B, Marshall DF, Thomas WT, Ramsay L, Mackay I, Balding DJ, Consortium AGOUEB, Waugh R, O'Sullivan DM (2010) Genome-wide association mapping to candidate polymorphism resolution in the unsequenced barley genome. Proc Natl Acad Sci U S A 107:21611-21616

Comadran J, Kilian B, Russell J, Ramsay L, Stein N, Ganal M, Shaw P, Bayer M, Thomas W, Marshall D, Hedley P, Tondelli A, Pecchioni N, Francia E, Korzun V, Walther A, Waugh R (2012) A homologue of Antirrhinum CENTRORADIALIS is a component of the quantitative photoperiod and vernalization independent EARLINESS PER SE 2 locus in cultivated barley. Nat Genet (in press)

Distelfeld A, Uauy C, Olmos S, Schlatter AR, Dubcovsky J, Fahima T (2004) Microcolinearity between a 2-cM region encompassing the grain protein content locus $\mathrm{Gpc}-6 \mathrm{~B} 1$ on wheat chromosome $6 \mathrm{~B}$ and a $350-\mathrm{kb}$ region on rice chromosome 2. Funct Integr Genom 4:59-66

Distelfeld A, Pearce SP, Avni R, Scherer B, Uauy C, Piston F, Slade A, Zhao R, Dubcovsky J (2012) Divergent functions of orthologous NAC transcription factors in wheat and rice. Plant Mol Biol 78:515-524

Dolezel J, Kubalakova M, Paux E, Bartos J, Feuillet C (2007) Chromosome-based genomics in the cereals. Chromosome Res 15:51-66

Dolezel J, Vrana J, Safar J, Bartos J, Kubalakova M, Simkova H (2012) Chromosomes in the flow to simplifying genome analysis. Funct Integr Genom 12:397-416

Duan J, Wu J, Liu Y, Xiao J, Ziao J, Zhao G, Jia J, Kong X (2012) New cis-regulatory elements in the Rht-D1 locus region of wheat. Funct Integr Genom 12:489-500

Dubcovsky J, Dvorak J (1995) Ribosomal RNA multigene loci: nomads of the Triticeae genomes. Genetics 140:1367-1377

Dubcovsky J, Dvorak J (2007) Genome plasticity a key factor in the success of polyploid wheat under domestication. Science 316:1862-1866

Elshire RJ, Glaubitz JC, Sun Q, Poland JA, Kawamoto K, Buckler ES, Mitchell SE (2011) A robust, simple genotyping-by-sequencing (GBS) approach for high diversity species. PLoS One 6:e19379
Faris JD, Zhang Z, Lu H, Lu S, Reddy L, Cloutier S, Fellers JP, Meinhardt SW, Rasmussen JB, Xu SS, Oliver RP, Simons KJ, Friesen TL (2010) A unique wheat disease resistance-like gene governs effector-triggered susceptibility to necrotrophic pathogens. Proc Natl Acad Sci U S A 107:13544-13549

Feuillet C, Eversole K (2007) Physical mapping of the wheat genome: a coordinated effort to lay the foundation for genome sequencing and develop tools for breeders. Isr J Plant Sci 5:307-313

Feuillet C, Leach JE, Rogers J, Schnable PS, Eversole K (2011) Crop genome sequencing: lessons and rationales. Trends Plant Sci $16: 77-88$

Flavell AJ, Knox MR, Pearce SR, Ellis THN (1998) Retrotransposonbased insertion polymorphisms (RBIP) for high throughput marker analysis. Plant J 16:643-650

Frenkel Z, Paux E, Mester D, Feuillet C, Korol A (2010) LTC: a novel algorithm to improve the efficiency of contig assembly for physical mapping in complex genomes. BMC Bioinforma 11:584

Fu D, Uauy C, Distelfeld A, Blechl A, Epstein L, Chen X, Sela H, Fahima T, Dubcovsky J (2009) A kinase-START gene confers temperature-dependent resistance to wheat stripe rust. Science 323:1357-1360

Fu Y, Springer NM, Ying K, Yeh C-T, Iniguez AL et al (2010) Highresolution genotyping via whole genome hybridizations to microarrays containing long oligonucleotide probes. PLoS One 5: e14178

Gottwald S, Bauer P, Komatsuda T, Lundqvist U, Stein N (2009) TILLING in the two-rowed barley cultivar 'Barke' reveals preferred sites of functional diversity in the gene HvHoxI. BMC Res Notes 2:258

Heffner EL, Lorenz AJ, Jannink J-L, Sorrells ME (2010) Plant breeding with genomic selection: gain per unit time and cost. Crop Sci 50:1681-1690

Hernandez P, Martis M, Dorado G, Pfeifer M, Galvez S, Schaaf S, Jouve N, Simkova H, Valarik M, Dolezel J, Mayer KF (2012) Next-generation sequencing and syntenic integration of flowsorted arms of wheat chromosome 4A exposes the chromosome structure and gene content. Plant J. doi:10.1111/j.13651313X.2011.04808.x

Houston K, Druka A, Bonar N, Macaulay M, Lundqvist U, Franckowiak J, Morgante M, Stein N, Waugh R (2012) Analysis of the barley bract suppression gene Trd1. Theor Appl Genet 125:33-45

Huang L, Brooks SA, Li W, Fellers JP, Trick HN, Gill BS (2003) Mapbased cloning of leaf rust resistance gene Lr21 from the large and polyploid genome of bread wheat. Genetics 164:655-664

Huang BE, George AW, Forrest KL, Kilian A, Hayden MJ, Morell MK, Cavanagh CR (2012) A multiparent advanced generation inter-cross population for genetic analysis in wheat. Plant Biotech J. doi:10.1111/j.1467-7652.2012.00702.x

Hui L, McNicol J, Bayer M, Morris JA, Cardle L, Marshall DF, Schulte D, Stein N, Shi B-J, Taudien S, Waugh R, Hedley PE (2011) Highly parallel gene-to-BAC addressing using microarrays. Biotechniques 50:165-174. doi:10.2144/000113627

International Barley Genome Sequencing Consortium (IBSC) (2012) A physical, genetic and functional sequence assembly of the barley genome. Nature (Lond). doi:10.1038/Nature11543

International Brachypodium Initiative (IBI) (2010) Genome sequencing and analysis of the model grass Brachypodium distachyon. Nature 463:763-768

International Rice Genome Sequencing Project (2005) The map-based sequence of the rice genome. Nature 436(7052):793-800

Kanisay L, Dawe RK (2009) Centromeres: long interspersed spaces with adaptive features. Funct Integr Genom 9:287-292

Komatsuda T, Pourkheirandish M, He C, Azhaguvel P, Kanamori H, Perovic D, Stein N, Graner A, Wicker T, Tagiri A, Lundqvist U, Fujimura T, Matsuoka M, Matsumoto T, Yano M (2007) Sixrowed barley originated from a mutation in a homeodomain- 
leucine zipper I-class homeobox gene. Proc Natl Acad Sci U S A 104(4):1424-1429

Krattinger S, Wicker T, Keller B (2009) Map-based cloning of genes in Triticeae (wheat and barley). In: Feuillet C, Muehlbauer GJ (eds) Genetics and genomics of the Triticeae. Springer, New York, pp 337-357

Krattinger SG, Lagudah ES, Wicker T, Risk JM, Ashton AR, Selter LL, Matsumoto T, Keller B (2011) Lr34 multi-pathogen resistance $\mathrm{ABC}$ transporter: molecular analysis of homoeologous and orthologous genes in hexaploid wheat and other grass species. Plant J 65(3):392-403

Kumar A, Bassi F, Paux E, Al-Azzam O, Michalack de Jimenez M, Denton AM, Gu YQ, Iqbal MJ, Huttner E, Kilian A, Kumar S, Goyal A, Tiwari V, Dogramaci M, Balyan HS, Dhaliwal HS, Gupta PK, Randhawa GS, Feuillet C, Pawlowski WP, Kianian SF (2012) DNA repair and crossing over favor similar chromosome regions as discovered in radiation hybrid of Triticum. BMC Genom 13(1):339

Lazo GR, Chao S, Hummel DD, Edwards H, Crossman CC, Lui N, Matthews DE, Carollo VL, Hane DL, You FM, Butler GE, Miller RE, Close TJ, Peng JH, Lapitan NLV, Gustafson JP, Qi LL, Echalier B, Gill BS, Dilbirligi M, Randhawa HS, Gill KS, Greene RA, Sorrells ME, Akhunov ED, Dvorak J, Linkiewicz AM, Dubcovsky J, Hossain KG, Kalavacharla V, Kianian SF, Mahmoud AA, Miftahudin X-F, Ma EJ, Conley JA, Anderson MS, Pathan HT, Nguyen PE, McGuire COQ, Anderson OD (2004) Development of an expressed sequence tag (EST) resource for wheat (Triticum aestivum L.): EST generation, unigene analysis, probe selection and bioinformatics for a 16,000-locus bindelineated map. Genetics 168:585-593

Le Couviour F, Faure S, Poupard B, Flodrops Y, Dubreuil P, Praud S (2011) Analysis of genetic structure in a panel of elite wheat varieties and relevance for association mapping. Theor Appl Genet 123(5):715-727

Leroy P, Guilhot N, Sakai H, Bernard A, Choulet F, Theil S, Reboux S, Amano N, Flutre T, Pellegrin C, Ohyanagi H, Seidel M, Giacomoni F, Reichstadt M, Alaux M, Gicquello E, Legeai F, Cerutti L, Tanaka T, Mayer K, Itoh T, Quesneville H, Feuillet C (2012) TriAnnot: a versatile and high performance pipeline for the automated annotation of plant genomes. Front Plant Sci 3:1-14

Liu Y, He Z, Appels R, Xia X (2012) Functional markers in wheat: current status and future prospects. Theor Appl Genet 125:1-10

Luo MC, Thomas C, You FM, Hsiao J, Ouyang S, Buell CR, Malandro M, McGuire PE, Anderson OD, Dvorak J (2003) Highthroughput fingerprinting of bacterial artificial chromosomes using the snapshot labeling kit and sizing of restriction fragments by capillary electrophoresis. Genomics 82:378-389

Mackay I, Powell W (2007) Methods for linkage disequilibrium mapping in crops. Trends Plant Sci 12:57-63

Mayer KF, Taudien S, Martis M, Simková H, Suchánková P, Gundlach H, Wicker T, Petzold A, Felder M, Steuernagel B, Scholz U, Graner A, Platzer M, Dolezel J, Stein N (2009) Gene content and virtual gene order of barley chromosome 1H. Plant Physiol 151:496-505

Mayer KF, Martis M, Hedley PE, Simková H, Liu H, Morris JA, Steuernagel B, Taudien S, Roessner S, Gundlach H, Kubaláková M, Suchánková P, Murat F, Felder M, Nussbaumer T, Graner A, Salse J, Endo T, Sakai H, Tanaka T, Itoh T, Sato K, Platzer M, Matsumoto T, Scholz U, Dolezel J, Waugh R, Stein N (2011) Unlocking the barley genome by chromosomal and comparative genomics. Plant Cell 23:1249-1263

Meuwissen TH (2009) Accuracy of breeding values of 'unrelated' individuals predicted by dense SNP genotyping. Genet Sel Evol $41: 35$

Miedaner T, Korzun V (2012) Marker-assisted selection for disease resistance in wheat and barley breeding. Phytopathology 102:560-566
Muñoz-Amatriaín M, Moscou MJ, Bhat PR, Svensson JT, Bartoš J, Suchánková P, Šimková H, Endo TR, Fenton RD, Lonardi S, Castillo AM, Chao S, Cistué L, Cuesta-Marcos A, Forrest KL, Hayden MJ, Hayes PM, Horsley RD, Makoto K, Moody D, Sato K, Vallés MP, Wulff BBH, Muehlbauer GJ, Doležel J, Close TJ (2011) An improved consensus linkage map of barley based on flow-sorted chromosomes and single nucleotide polymorphism markers. Plant Genome 4:238-249

Nair SK, Wang N, Turuspekov Y, Pourkheirandish M, Sinsuwongwat S, Chen G, Sameri M, Tagiri A, Honda I, Watanabe Y, Kanamori H, Wicker T, Stein N, Nagamura Y, Matsumoto T, Komatsuda T (2010) Cleistogamous flowering in barley arises from the suppression of microRNA-guided HvAP2 mRNA cleavage. Proc Natl Acad Sci U S A 107(1):490-495

Paterson AH, Bowers JE, Bruggmann R, Dubchak I, Grimwood J, Gundlach H, Haberer G, Hellsten U, Mitros T, Poliakov A, Schmutz J, Spannagl M, Tang H, Wang X, Wicker T, Bharti AK, Chapman J, Feltus FA, Gowik U, Grigoriev IV, Lyons E, Maher CA, Martis M, Narechania A, Otillar RP, Penning BW, Salamov AA, Wang Y, Zhang L, Carpita NC, Freeling M, Gingle AR, Hash CT, Keller B, Klein P, Kresovich S, McCann MC, Ming R, Peterson DG, Mehboob ur R, Ware D, Westhoff P, Mayer KFX, Messing J, Rokhsar DS (2009) The Sorghum bicolor genome and the diversification of grasses. Nature 457:551-556

Paux E, Sourdille P, Salse J, Saintenac C, Choulet F, Leroy P, Korol A, Michalak M, Kianian S, Spielmeyer W, Lagudah E, Somers D, Kilian A, Alaux M, Vautrin S, Berges H, Eversole K, Appels R, Safar J, Simkova H, Dolezel J, Bernard M, Feuillet C (2008) A physical map of the 1-gigabase bread wheat chromosome $3 \mathrm{~B}$. Science 322:101-104

Paux E, Faure S, Choulet F, Roger D, Gauthier V, Martinant JP, Sourdille P, Balfourier F, Le Paslier MC, Chauveau A, Cakir M, Gandon B, Feuillet C (2010) Insertion site-based polymorphism markers open new perspectives for genome saturation and marker-assisted selection in wheat. Plant Biotechnol J 8:196-210

Paux E, Sourdille P, Mackay I, Feuillet C (2012) Sequence-based marker development in wheat: advances and applications to breeding. Biotechnol Adv 30(5):1071-1088

Philippe R, Choulet F, Paux E, van Oeveren J, Tang J, Wittenberg AH, Janssen A, van Eijk MJ, Stormo K, Alberti A, Wincker P, Akhunov E, van der Vossen E, Feuillet C (2012) Whole Genome Profiling provides a robust framework for physical mapping and sequencing in the highly complex and repetitive wheat genome. BMC Genom 13:47

Poland JA, Brown PJ, Sorrells ME, Jannink JL (2012) Development of high-density genetic maps for barley and wheat using a novel twoenzyme genotyping-by-sequencing approach. PLoS One 7:e32253

Quraishi UM, Abrouk M, Bolot S, Pont C, Throude M, Guilhot N, Confolent C, Bortolini F, Praud S, Murigneux A, Charmet G, Salse J (2009) Genomics in cereals: from genome-wide conserved orthologous set (COS) sequences to candidate genes for trait dissection. Funct Integr Genom 9:473-484

Reif JC, Gowda M, Maurer HP, Longin CF, Korzun V, Ebmeyer E, Bothe R, Pietsch C, Würschum T (2011) Association mapping for quality traits in soft winter wheat. Theor Appl Genet 122:961-970

Riera-Lizarazu O, Leonard JM, Tiwari VK, Kianian SF (2010) A method to produce radiation hybrids for the D-genome chromosomes of wheat (Triticum aestivum L.). Cytogenet Genome Res 129:234-240

Rustenholz C, Hedley PE, Morris J, Choulet F, Feuillet C, Waugh R, Paux E (2010) Specific patterns of gene space organisation revealed in wheat by using the combination of barley and wheat genomic resources. BMC Genom 11:714

Rustenholz C, Choulet F, Laugier C, Safar J, Simkova H, Dolezel J, Magni F, Scalabrin S, Cattonaro F, Vautrin S, Bellec A, Berges H, Feuillet C, Paux E (2011) A 3000-loci transcription map of 
chromosome 3B unravels the structural and functional features of gene islands in hexaploid wheat. Plant Physiol 157:1596-1608

Safar J, Bartos J, Janda J, Bellec A, Kubalakova M, Valarik M, Pateyron S, Weiserova J, Tuskova R, Chalkova J, Vrana J, Simkova H, Faivre-Rampant P, Sourdille P, Caboche M, Bernard M, Dolezel J, Chalhoub B (2004) Dissecting large and complex genomes: flow sorting and BAC cloning of individual chromosomes from bread wheat. Plant J 39:960-968

Šafář J, Šimková H, Kubaláková M, Č́íhalíková J, Suchánková P, Bartoš J, Doležel J (2010) Development of chromosome-specific BAC resources for genomics of bread wheat. Cytogenet Genome Res 1-13. doi:10.1159/000313072

Saintenac C, Falque M, Martin OC, Paux E, Feuillet C, Sourdille P (2009) Detailed recombination studies along chromosome 3B provide new insights on crossover distribution in wheat (Triticum aestivum L.). Genetics 181:393-403

Saintenac C, Jiang D, Akhunov ED (2011) Targeted analysis of nucleotide and copy number variation by exon capture in allotetraploid wheat genome. Genome Biol 12(9):R88

Salse J, Abrouk M, Bolot S, Guilhot N, Courcelle E, Faraut T, Waugh R, Close TJ, Messing J, Feuillet C (2009) Reconstruction of monocotelydoneous proto-chromosomes reveals faster evolution in plants than in animals. Proc Natl Acad Sci U S A 106:14908-14913

Schnable PS, Ware D, Fulton RS, Stein JC, Wei F, Pasternak S, Liang C, Zhang J, Fulton L, Graves TA, Minx P, Reily AD, Courtney L, Kruchowski SS, Tomlinson C, Strong C, Delehaunty K, Fronick C, Courtney B, Rock SM, Belter E, Du F, Kim K, Abbott RM, Cotton M, Levy A, Marchetto P, Ochoa K, Jackson SM, Gillam B, Chen W, Yan L, Higginbotham J, Cardenas M, Waligorski J, Applebaum E, Phelps L, Falcone J, Kanchi K, Thane T, Scimone A, Thane N, Henke J, Wang T, Ruppert J, Shah N, Rotter K, Hodges J, Ingenthron E, Cordes M, Kohlberg S, Sgro J, Delgado B, Mead K, Chinwalla A, Leonard S, Crouse K, Collura K, Kudrna D, Currie J, He R, Angelova A, Rajasekar S, Mueller T, Lomeli R, Scara G, Ko A, Delaney K, Wissotski M, Lopez G, Campos D, Braidotti M, Ashley E, Golser W, Kim H, Lee S, Lin J, Dujmic Z, Kim W, Talag J, Zuccolo A, Fan C, Sebastian A, Kramer M, Spiegel L, Nascimento L, Zutavern T, Miller B, Ambroise C, Muller S, Spooner W, Narechania A, Ren L, Wei S, Kumari S, Faga B, Levy MJ, McMahan L, Van Buren P, Vaughn MW et al (2009) The B73 maize genome: complexity, diversity, and dynamics. Science 326:1112-1115

Schulte D, Ariyadasa R, Shi B, Fleury D, Saski C, Atkins M, de Jong P, Wu CC, Graner A, Langridge P, Stein N (2011) BAC library resources for map-based cloning and physical map construction in barley (Hordeum vulgare L.). BMC Genom 12:247

Soderlund C, Humphray S, Dunham A, French L (2000) Contigs built with fingerprints, markers, and FPC V4.7. Genome Res 10:17721787

Sorrells ME, Gustafson JP, Somers D, Chao S, Benscher D, GuediraBrown G, Huttner E, Kilian A, McGuire PE, Ross K, Tanaka J, Wenzl P, Williams K, Qualset CO (2011) Reconstruction of the synthetic W7984 x Opata M85 wheat reference population. Genome 54:875-882

Stein N, Graner A (2004) Map-based gene isolation in cereal genomes. In: Gupta P, Varshney R (eds) Cereal genomics. Kluwer, Dordrecht, pp 331-360

Sutton T, Baumann U, Hayes J, Collins NC, Shi BJ, Schnurbusch T, Hay A, Mayo G, Pallotta M, Tester M, Langridge P (2007) Borontoxicity tolerance in barley arising from efflux transporter amplification. Science 318:1446-1449

Taketa S, Amano S, Tsujino Y, Sato T, Saisho D, Kakeda K, Nomura M, Suzuki T, Matsumoto T, Sato K, Kanamori H, Kawasaki S,
Takeda K (2008) Barley grain with adhering hulls is controlled by an ERF family transcription factor gene regulating a lipid biosynthesis pathway. Proc Natl Acad Sci U S A 105(10):4062-4067

Talamè V, Bovina R, Sanguineti MC, Tuberosa R, Lundqvist U, Salvi S (2008) TILLMore, a resource for the discovery of chemically induced mutants in barley. Plant Biotechnol J 6:477-485

Tsai H, Howell T, Nitcher R, Missirian V, Watson B, Ngo KJ, Lieberman M, Fass J, Uauy C, Tran RK, Khan AA, Filkov V, Tai TH, Dubcovsky J, Comai L (2011) Discovery of rare mutations in populations: TILLING by sequencing. Plant Physiol 156:1257-1268

Turner A, Beales J, Faure S, Dunford RP, Laurie DA (2005) The pseudo-response regulator Ppd-H1 provides adaptation to photoperiod in barley. Science 310(5750):1031-1034

van Oeveren J, de Ruiter M, Jesse T, van der Poel H, Tang JF, Yalcin F, Janssen A, Volpin H, Stormo KE, Bogden R et al (2011) Sequence-based physical mapping of complex genomes by whole genome profiling. Genome Res 21:618-625

Wicker T, Mayer KF, Gundlach H, Martis M, Steuernagel B, Scholz U, Simková H, Kubaláková M, Choulet F, Taudien S, Platzer M, Feuillet C, Fahima T, Budak H, Dolezel J, Keller B, Stein N (2011) Frequent gene movement and pseudogene evolution is common to the large and complex genomes of wheat, barley, and their relatives. Plant Cell 23:1706-1718

Winfield MO, Wilkinson PA, Allen AM, Barker GL, Coghill JA, Burridge A, Hall A, Brenchley RC, D'Amore R, Hall N, Bevan MW, Richmond T, Gerhardt DJ, Jeddeloh JA, Edwards KJ (2012) Targeted re-sequencing of the allohexaploid wheat exome. Plant Biotechnol J 10:733-742

Xia Y, Ning Z, Bai G, Li R, Yan G, Siddique KH, Baum M, Guo P (2012) Allelic variations of a light harvesting chlorophyll a/bbinding protein gene (Lhcb1) associated with agronomic traits in barley. PLoS One 7(5):e37573

Yan L, Loukoianov A, Tranquilli G, Helguera M, Fahima T, Dubcovsky J (2003) Positional cloning of wheat vernalization gene VRN1. Proc Natl Acad Sci U S A 100:6263-6268

Yan L, Loukoianov A, Blechl A, Tranquilli G, Ramakrishna W, SanMiguel P, Bennetzen JL, Echenique V, Dubcovsky J (2004) The wheat VRN2 gene is a flowering repressor down-regulated by vernalization. Science 303:1640-1644

Yan L, Fu D, Li C, Blechl A, Tranquilli G, Bonafede M, Sanchez A, Valarik M, Yasuda S, Dubcovsky J (2006) The wheat and barley vernalization gene VRN3 is an orthologue of FT. Proc Natl Acad Sci U S A 103:19581-19586

Yoshida T, Nishida H, Zhu J, Nitcher R, Distelfeld A, Akashi Y, Kato $\mathrm{K}$, Dubcovsky J (2010) Vrn-D4 is a vernalization gene located on the centromeric region of chromosome $5 \mathrm{D}$ in hexaploid wheat. Theor Appl Genet 120:543-552

Yuo T, Yamashita Y, Kanamori H, Matsumoto T, Lundqvist U, Sato K, Ichii M, Jobling SA, Taketa S (2012) A short internodes (SHI) family transcription factor gene regulates awn elongation and pistil morphology in barley. J Exp Bot 63(14):5223-5232

Zhang H, Sreenivasulu N, Weschke W, Stein N, Rudd S, Radchuk V, Potokina E, Scholz U, Schweizer P, Zierold U, Langridge P, Varshney RK, Wobus U, Graner A (2004) Large-scale analysis of the barley transcriptome based on expressed sequence tags. Plant J 40:276-290

Zhang G, Liu X, Quan Z, Cheng S, Xu X, Pan S, Xie M, Zeng P, Yue Z, Wang W, Tao Y, Bian C, Han C, Xia Q, Peng X, Cao R, Yang X, Zhan D, Hu J, Zhang Y, Li H, Li H, Li N, Wang J, Wang C, Wang R, Guo T, Cai Y, Liu C, Xiang H, Shi Q, Huang P, Chen Q, Li Y, Wang J, Zhao Z, Wang J (2012) Genome sequence of foxtail millet (Setaria italica) provides insights into grass evolution and biofuel potential. Nat Biotech 30:549-554 